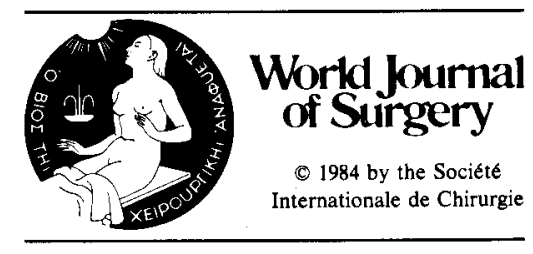

\title{
Segmental Pancreatic Transplantation with Enteric Exocrine Diversion
}

\author{
Carl-Gustav Groth, M.D., Gunnar Tydén, M.D., Göran Lundgren, M.D., Henryk Wilczek, M.D., \\ Göran Klintmalm, M.D., Lennart Öst, M.D., Rolf Gunnarsson, M.D., and Jan Östman, M.D. \\ Departments of Transplantation Surgery and Medicine, Karolinska Institute, Huddinge Hospital, Stockholm, Sweden
}

Fourteen combined cadaveric renal and segmental pancreatic transplantations with both of the organs provided by the same donor were performed, and exocrine diversion was to the recipient's bowel. Nine of the grafts have failed because of technical surgical complications, and 2 grafts failed because of rejection. Three patients are carrying well-functioning grafts 6,19 , and 24 months, respectively, after transplantation. Ten of the kidneys are functioning; thus, the use of combined transplantation has not jeopardized the results of renal grafting. Patients who had functioning pancreatic grafts had normal or near-normal fasting blood glucose levels; studies of intravenous glucose tolerance test revealed $k$-values around or just over 1.0 and glycosylated hemoglobin levels were normal. When azathioprine was replaced with cyclosporine, 4 of 6 patients showed a significant decline in $k$-value. This deterioration in blood glucose control was reversible by dosage adjustment.

Segmental pancreatic transplantation for the treatment of diabetes mellitus in humans has proven increasingly successful in recent years. Nevertheless, the results of pancreatic transplantation are significantly inferior to those of the transplantation of other organs, such as the kidney and the heart. We believe that the main reason for this lies in the fact that the surgical technical problems of pancreatic transplantation have not been solved. On the other hand, patients who have retained their grafts have achieved excellent control of their glucose homeostasis.

In our institution, 14 segmental pancreatic transplantations were performed between 1974 and 1981.

Reprint requests: C.-G. Groth, M.D., Department of Transplantation Surgery, Huddinge Hospital, S-141 86 Huddinge, Sweden.
In 10 instances the exocrine secretion was diverted to the bowel either by end-to-end pancreaticoenterostomy or by end-to-side ductoenterostomy; in 4 transplantations, the pancreatic duct was simply ligated [1-4]. In most of the recipients, the postoperative course was marred by technico-surgical complications related to the pancreatic juice and in no instance was graft function beyond 2 months achieved [5].

Since 1981 , we have performed 14 additional segmental pancreatic transplantations. Enteric exocrine diversion was again used but with several modifications in technical details. In this series the incidence of exocrine leakage has been much reduced and in some of the patients, long-term success has been achieved. This paper reviews this recent experience; special emphasis has been placed on the metabolic findings in the patients who retained their grafts for several months or years.

\section{Methods}

Fourteen combined cadaveric renal and segmental pancreatic transplantations, with both of the organs provided by the same donor, were performed between November, 1981, and October, 1983. All of the patients suffered from juvenile diabetes of long standing (19-24 years); their age range was 25-47 years.

The vessels of the segmental pancreatic graft (body and tail) were anastomosed to the patient's iliac vessels and the graft was placed intraperitoneally. The cut end of the pancreatic graft was anastomosed end-to-end to a Roux-en-Y jejunal loop and a catheter was placed in the pancreatic duct to temporarily divert the secretion to the exterior [6]. The simultaneously transplanted kidney was anasto- 


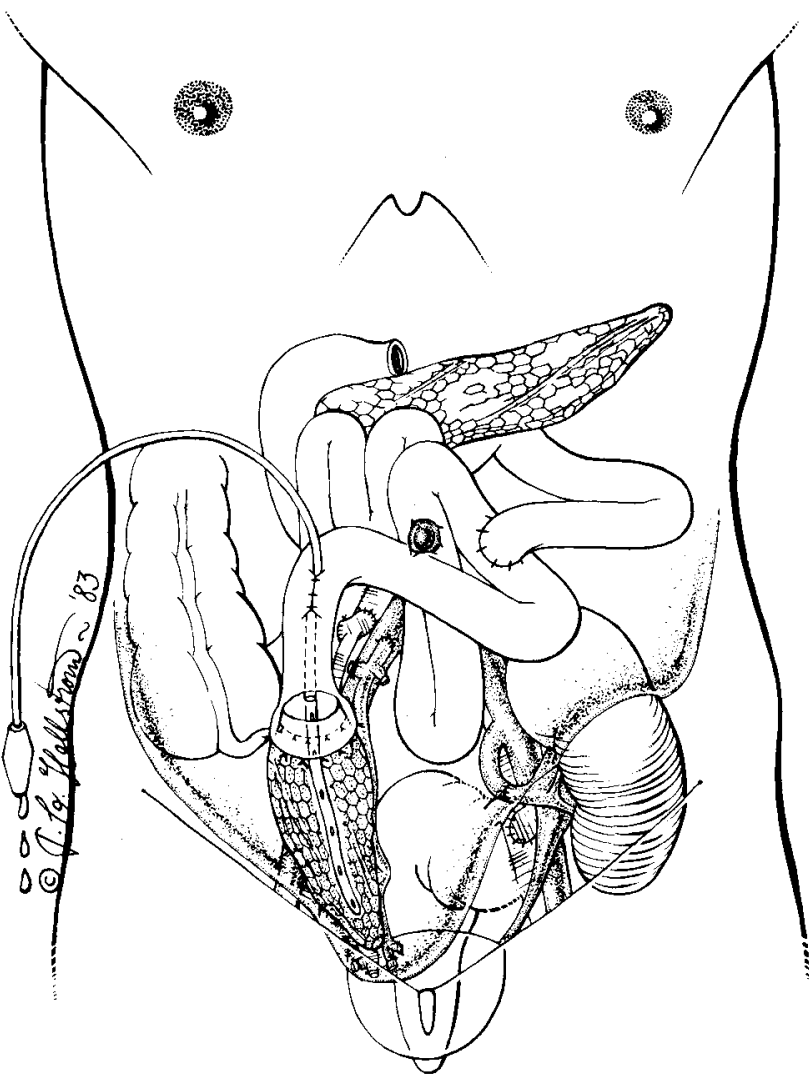

Fig. 1. Technique used for intraperitoneal segmental pancreatic transplantation with pancreaticoenterostomy to a jejunal Roux-en-Y loop with temporary pancreatic duct tube drainage to the exterior. The concomitantly transplanted kidney is placed extraperitoneally on the contralateral side. (Illustration reprinted with permission from T. Hellström.)

mosed to the opposite iliac vessels and was placed extraperitoneally (Fig. 1). Immunosuppression consisted of azathioprine, prednisone, and rabbit antithymocyte globulin. In 6 patients azathioprine was replaced by cyclosporine one or more months after transplantation. Rejection was treated with 0.25 to $1 \mathrm{~g}$ doses of methylprednisolone given intravenously over several days.

\section{Results}

In 1 patient the pancreatic graft was removed perioperatively because of a preservation injury and this patient did not receive a renal graft. In all the other patients, exogenous insulin was withdrawn immediately following transplantation and fasting blood glucose was usually normal or near-normal within a few hours. Seven pancreatic grafts were lost within 1 month for the following reasons: irreversible graft rejection (1), exocrine leakage from the enteric anastomosis (1), graft thrombosis (3), abdominal wall abscess formation (1), and per- foration of the left colon (1). One of the patients with graft thrombosis had an abdominal abscess foregoing this event probably because of an anastomotic leakage. One of these patients died. Six grafts have functioned for more than 2 months. Of these, one was lost because of graft thrombosis in conjunction with myocardial infarction after 2.5 months. One patient had an irreversible rejection of the renal graft with no sign of pancreatic graft involvement after 4 months. This patient was readmitted to peritoneal dialysis and subsequently died of cardiac failure while the pancreatic graft was still functioning. In 1 patient who had had excellent graft function for 1.5 years, the graft was lost in irreversible rejection. At present 3 patients still have their pancreatic grafts 2 years, 19 months, and 6 months, respectively, after transplantation. Of the simultaneously transplanted kidneys, 2 have been lost because of irreversible rejection and 1 because of rejection after the withdrawal of immunosuppressive therapy. Thus, 10 of 13 renal grafts are currently functioning.

The 6 patients who had functioning grafts for more than 2 months all had normal or near-normal fasting blood glucose levels (Fig. 2). Studies of intravenous glucose tolerance tests ( $25 \mathrm{~g}$ glucose) have revealed values around or just over 1.0 (Fig. 3 ). When azathioprine was replaced by cyclosporine, 4 of the 6 patients showed a significant decline in the k-value. One patient (KD) was switched back to azathioprine because of multiple signs of cyclosporine toxicity; the k-value then promptly returned to normal. In 2 patients (SF, RJ), a restitution was achieved by cyclosporine dose adjustment. The fourth patient (SN) lost his graft in thrombosis before any such action was taken. $\mathrm{HbA}_{1}$ levels were normal in all patients, although serum creatinine was somewhat elevated, probably because of cyclosporine nephrotoxicity (Table 1). Studies of nerve conduction velocity $(\mathrm{ENeG})$ in the 3 patients who carried functioning pancreatic grafts for more than 1 year revealed some improvement at 1 year in all patients, but at 18 months there was a further improvement in 1 patient only (SF) (Fig. 4). This patient who had only mild retinopathy perioperatively also had an improvement in visual acuity 1.5 years after transplantation. Renal transplant biopsy carried out 15 months after transplantation in this patient showed no thickening of the glomerular basement membranes. Such a finding would have suggested a recurrence of diabetic nephropathy.

\section{Discussion}

Since the purpose of pancreatic transplantation is to prevent the secondary complications of diabetes, 
Fasting blood glucose, monthly mean values \pm SEM

(Figures in brackets denote no of determinations)
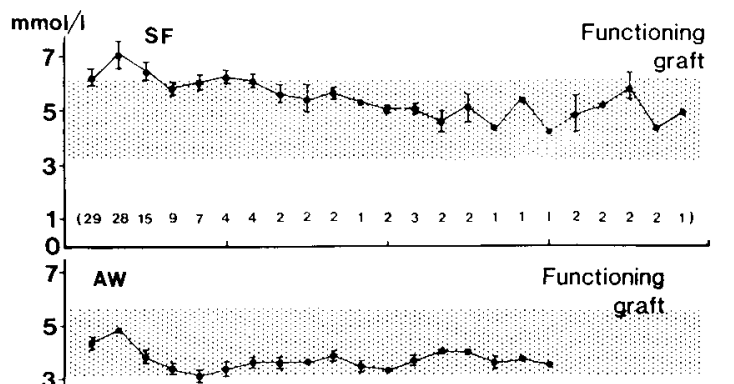

3

1. $\left(\begin{array}{llllllllllllllllll}29 & 28 & 14 & 10 & 6 & 5 & 8 & 3 & 3 & 6 & 2 & 1 & 11 & 1 & 1 & 2 & 1 & 1\end{array}\right)$
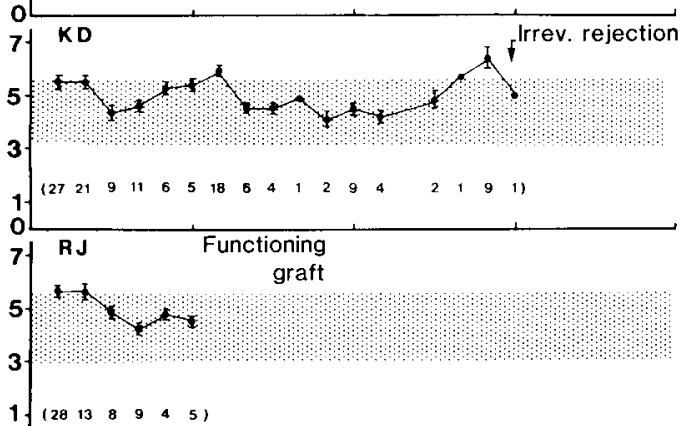

1. $\left(\begin{array}{llllll}28 & 13 & 8 & 9 & 4 & 5\end{array}\right)$
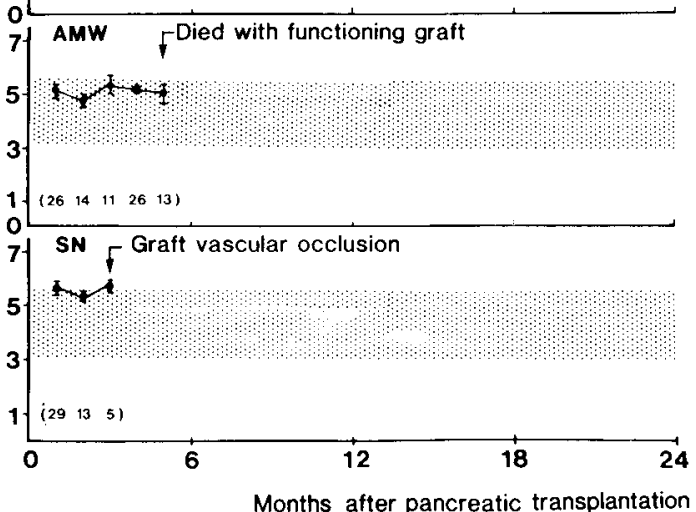

K-value, IVGTT $25 \mathrm{~g}$
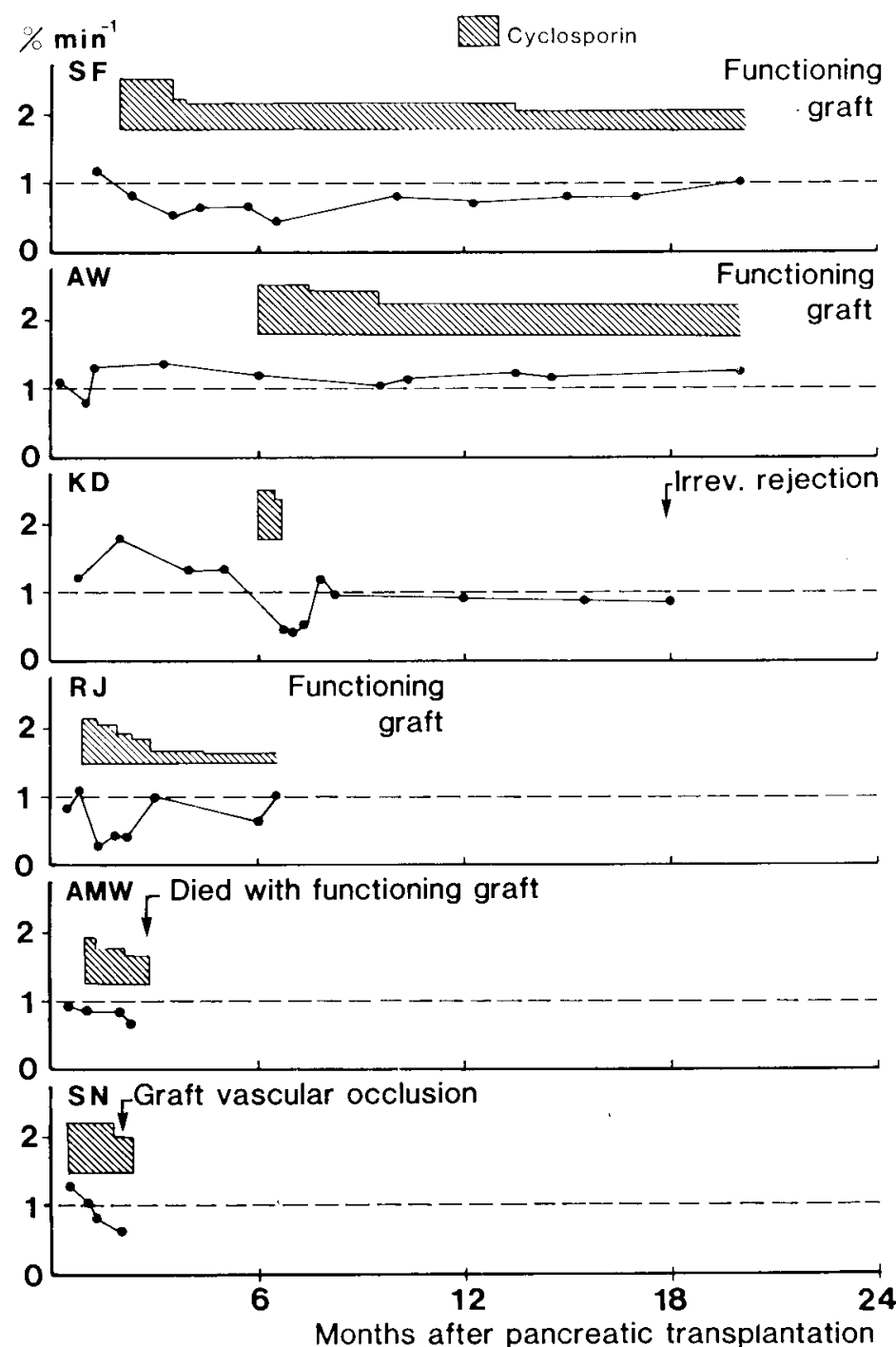

Fig. 2. Fasting blood glucose after segmental pancreatic transplantation in 6 patients (left).

Fig. 3. Intravenous glucose tolerance tests after segmental pancreatic transplantation in 6 patients. Note decline of the kvalue in 4 patients when cyclosporine was given (right).

the procedure should ideally be undertaken before multiple organ damage has occurred. However, the experimental nature of the operation and the hazard of the immunosuppressive treatment have prompted us for the time being to transplant the pancreas only to uremic diabetics who are to receive renal grafts; these patients would require immunosuppressive therapy in any case for the renal graft. The renal and pancreatic transplantations can be performed simultaneously, thus avoiding 2 separate operative procedures. Another advantage of this approach is that the high-dose immunosuppression usually given immediately after transplantation does not have to be repeated.

The handling of the exocrine secretion has been a major stumbling-block in segmental pancreatic transplantation. The most physiological approach would obviously be to divert the secretion to the bowel by pancreaticoenterostomy or ductoenterostomy, as is done after pancreaticoduodenectomy for malignancy (Whipple procedure). In some animal experiments, these techniques have also been used with reasonable success in conjunction with pancreatic transplantations. However, initial clinical experience with segmental pancreatic transplantation and enteric diversion was discouraging. Pancreatic fistula almost invariably occurred and when the fistula came from a pancreaticoenteric anastomosis, it became infected with enteric bacteria. In some cases this dangerous complication necessitat- 
Table 1. Glycosylated hemoglobin ( $\mathrm{HbA}_{1}$-levels) and serum creatinine in 4 insulin-dependent diabetics after pancreatic transplantation.

\begin{tabular}{lllll}
\hline & $\begin{array}{l}\mathrm{HbA}_{1} \\
\text { (ref }\end{array}$ & $\begin{array}{l}\text { Number } \\
\text { of deter- } \\
\text { minations }\end{array}$ & $\begin{array}{l}\text { Time after } \\
\text { pancreatic } \\
\text { transplantation } \\
\text { (months) }\end{array}$ & $\begin{array}{l}\text { Serum- } \\
\text { creati- } \\
\text { nine } \\
(\mu \mathrm{mol} / \mathrm{L})\end{array}$ \\
\hline tient & $<8.5)$ & & $14-22$ & $228-196$ \\
S.F. & $8.0 \pm 0.2$ & 6 & $8-16$ & $158-178$ \\
A.W. & $6.3 \pm 0.3$ & 7 & $8-15$ & $157-169$ \\
K.D. & $7.8 \pm 0.4$ & 6 & $1-3$ & $188-265$ \\
R.J. & $6.8 \pm 0.1$ & 3 & &
\end{tabular}

ed the removal of a well-functioning graft; in others it made the treatment of an acute rejection episode too risky and thus indirectly caused the loss of the graft [1-5].

However, fellowing modifications of various details [6], we have recently been able to use pancreaticojejunostomy with some success. We believe that the use of intra- instead of extraperitoneal placement of the graft has provided better conditions for anastomotic healing. Pancreatic duct drainage to the exterior via a catheter was introduced in the hope that this would allow the anastomosis to heal without being exposed to the digestive action of the pancreatic secretion. However, in some patients the catheter did not function and in others it functioned for only a few days. In 1 of the 2 patients who developed an anastomotic leak, the catheter never functioned; in the other, it functioned for 3 days only.

A high incidence of graft vascular occlusions, as seen in this series, has been seen in all large series of pancreatic transplantations. One explanation of this may well be the abnormal hemodynamic situation of the segmental pancreatic vessels since the large splenic artery is left to drain via the small pancreatic vessels. Such a poor run-off must increase the risk of thrombosis formation. Unfortunately, it seems that treatment with the powerful anticoagulant drug, warfarin, does not avert this problem [5].

It is encouraging that the patients in whom technical complications and graft rejections were avoided had such good control of the blood glucose homeostasis, as reflected by the intravenous glucose tolerance tests and glucosylated hemoglobin levels. In this context the finding that cyclosporine may cause a deterioration in glucose control is worrisome [7]. The future role of cyclosporine in pancreatic transplantation will have to be assessed with this finding in mind.

The real benefit of pancreatic transplantation consists in the prevention or reversal of the secondary complications of the disease. So far the number

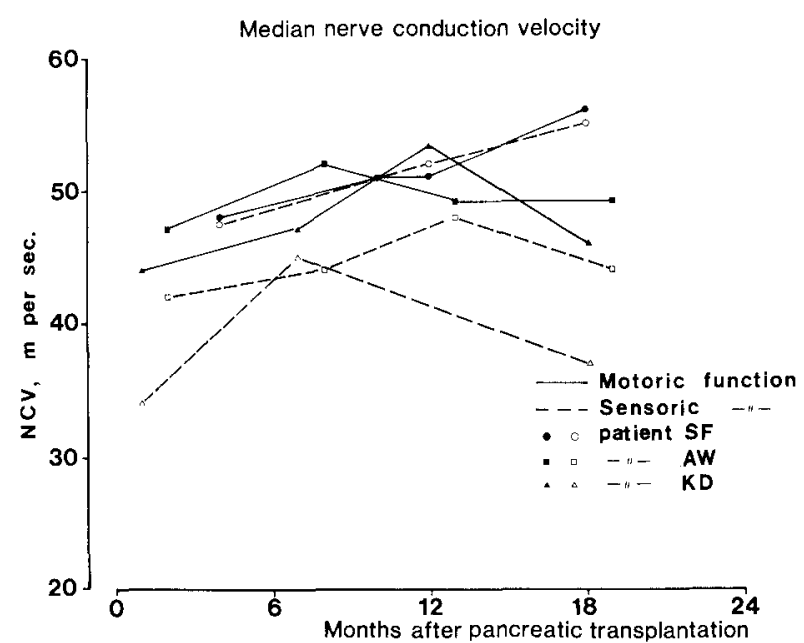

Fig. 4. Nerve conduction velocity in the median nerve after segmental pancreatic transplantation in 3 patients.

of patients who have had pancreatic grafts for any length of time has been small. Moreover, many of the patients had very severe secondary lesions at the time of transplantation, which made it difficult to assess any effect on the lesions. In 1 of the patients there was, however, sustained improvement in nerve conduction velocity and an improvement in the visual acuity. Since the patients had both uremia and diabetes at the time of transplantation, such a recovery might be due to an improvement in the uremic state [8] as well as to the improvement in blood glucose control. The fact that no increase in glomerular basement membrane thickness has occurred in this patient's renal graft should, however, be a reflection of the good blood glucose control. Further studies in this regard are much needed.

In this series of 14 combined segmental pancreatic and renal transplantations, the complication rate has been acceptable. The use of combined transplantation seems not to have jeopardized the results of renal grafting. The patients who have retained well-functioning pancreatic grafts have had good or excellent glucose control.

\section{Résumé}

Quatorze greffes segmentaires de pancréas ont été pratiquées en même temps qu'une greffe de rein de cadavre provenant du même donneur, avec dérivation des sécrétions pancréatiques exocrines vers l'intestin du receveur. Neuf greffes ont échoué par suite de complications de la technique chirurgicale, deux en raison d'un rejet. Trois patients sont porteurs de greffes fonctionnelles, respectivement, 6, 19 et 24 mois après transplantation. Dix des reins 
greffés sont fonctionnels, la transplantation combinée n'a donc pas compromis les résultats de la greffe rénale. Les patients dont les greffons sont fonctionnels ont des glycémies à jeun normales ou quasinormales; les épreuves d'hyperglycémie provoquée par voie veineuse ont donné des valeurs de $\mathrm{k}$ voisines ou à peine au-dessus de 1.0 et les taux d'hémoglobine glycosylée sont normaux. Le remplacement de l'azathioprine par la cyclosporine a entraîné chez 4 patients sur 6 une diminution significative de leurs valeurs de $\mathrm{k}$. Cette dégradation du contrôle glycémique s'est avérée réversible après adaptation des doses.

\section{Resumen}

Catorce pacientes fueron sometidos a transplante combinado de páncreas parcial y riñon con ambos órganos provenientes del mismo donante cadavérico. Las secreciones exocrinas fueron drenadas al tracto gastrointestinal del recipiente. Nueve injertos han fallado debido a complicaciones técnicas quirúrgicas y dos injertos han sido rechazados. Tres pacientes tienen injertos funcionando 6,19 y 24 meses después del transplante. Diez de los riñones están funcionando lo que indica que el transplante combinado no ha comprometido los resultados del injerto renal. Pacientes con buena función del injerto pancreático demostraron niveles de glicemia en ayuno normales o casi normales. Estudios de la prueba intravenosa de tolerancia a la glucosa demostró valores $\mathrm{k}$ de alrededor de 1.0. Los niveles de hemoglobina glicosilada eran normales. Cuando azatioprina fue reemplazada con ciclosporina 4 de 6 pacientes demonstraron una declinación en el valor k. Este deterioro en el control de la glicemia fue revertido con ajustes de dosis.

\section{References}

1. Groth, C.G., Lundgren, G., Arner, P., Collste, H., Hårdstedt, C., Lewander, R., Östman, J.: Rejection of isolated pancreatic allografts in patients with diabetes. Surg. Gynecol. Obstet. 143:933, 1976

2. Groth, C.G., Lundgren, G., Gunnarsson, R., Hårdstedt, C., Östman, J.: Segmental pancreatic transplantation, with special reference to the use of ileal exocrine diversion and to the hemodynamics of the graft. Transplant. Proc. 12[Suppl. 2]:62, 1980

3. Groth, C.G., Lundgren, G., Gunnarsson, R., Arner, P., Berg, B., Östman, J.: Segmental pancreatic transplantation with duct ligation or drainage to a jejunal Roux-en-Y loop in non-uremic diabetic patients. Diabetes 29[Suppl. 1]:3, 1980

4. Groth, C.G., Collste, H., Lundgren, G., Ringdén, O., Thulin, L., Wilczek, H., Gunnarsson, R., Östman, J.: Surgical techniques for pancreatic transplantation. A critical appraisal of methods used and a suggested new modification. Horm. Metab. Res. [Suppl. 3]:37, 1983

5. Groth, C.G., Lundgren, G., Wilczek, H., Klintmalm, G., Tydén G., Gunnarsson, R., Östman, J.: Segmental pancreatic transplantation with duct ligature or enteric diversion: Technical aspects. Transplant. Proc. (in press)

6. Groth, C.G., Collste, H., Lundgren, G., Wilczek, H., Klintmalm, G., Ringdén, O., Gunnarsson, R., Östman, J.: Successful outcome of segmental human pancreatic transplantation with enteric exocrine diversion after modifications in technique. Lancet 2:522, 1982

7. Gunnarsson, R., Klintmalm, G., Lundgren, G., Tydén, G., Wilzek, H., Östman, J., Groth, C.G.: Deterioration in glucose metabolism in pancreatic transplant recipients after conversion from azathioprine to cyclosporin. Lancet 2:571, 1983

8. Najarian, J., Sutherland, D., Simmons, R., Howard, R., Kjellstrand, C., Mauer, M., Kennedy, W., Ramsay, R., Barbosa, J., Goetz, F.: Kidney transplantation for the uremic diabetic patient. Surg. Gynecol. Obstet. 144:682, 1977 